\title{
Muhasebe Dersinde Başarıyı Etkileyen Faktörlerin Belirlenmesi: Kahramanmaraş Sütçü İmam Üniversitesi Örneği
}

\author{
Ahmet ŞERBETÇI I $^{*}$ \\ Mahmut YARDIMCIOĞLU**
}

\section{ÖZET}

Bu çalışmada üniversitede bulunan ögrencilerin muhasebe dersine ilişkin başarılarını etkileyen faktörlerin tespit edilip elde edilen sonuç doğrultusunda bu faktörlerle ilgili çalışmalar yapılarak bireyin akademik eğitim kalitesinin arttırlması amaçlanmıştır. Yapılan bu araştırmanın ana kütlesi için Kahramanmaraş Sütçü İmam Üniversitesi Ikktisadi ve idari Bilimler Fakültesi Iş̧letme Bölümü'nde okuyan Genel Muhasebe-1 dersini almış, birinci sınıf (İkinci Öğretim) öğrencileri ve aynı dersten tekrara kalan (İkinci Öğretim) ögrenciler başarı düzeylerinden dolayı seçilmiş̧tir. Doldurulması istenilen 63 sorudan oluşan toplam 180 anketin tamamı ögrenciler tarafindan cevaplanmış olup çalışmada bu anketlerden elde edilen veri setinden yararlanılmıştır. Sorular, ögrencilerin sosyodemografik özellikleri, alınmış olan Genel Muhasebe-1 dersiyle ilgili mevcut durum ve düşünceler ile muhasebe dersinde başarıyı etkileyebileceği düşünülen faktörlerden oluşmaktadır. Çalışmada muhasebe eğitimi ile ilgili genel bilgiler verilmiş ve başarı düzeyinde etkili olan 16 açıklayıcı değişkenin varlığı tespit edilmiştir.

Anketlere verilen cevaplar SPSS paket programından yararlanılarak değerlendirilmiştir.

Anahtar Kelimeler: Muhasebe Dersi, Muhasebe Eğitimi, Başarıyı Etkileyen Faktörler.

JEL Sinıflandirması: M40, M49, A29.

\section{Determining The Factors That Affecting The Success In Accounting Lesson:}

\section{Kahramanmaraş Sütçü İmam University Sample}

\section{ABSTRACT}

The present study identifies the success factors of accounting course for the university students and aims to increase academic standards in light of the findings. Accounting course from Management Faculty of Kahramanmaras Sutcu Imam University is selected and freshmen (Secondary Education) students, both who are taking the course for the first time and who have failed before are in involved in this study. The data set utilized consists of a total 180 questionnaires, which include 63 questions filled in by the students. Questionnaire questions cover socio-demographic characteristics of the students, opinions about accounting course, and possible success factors. The study outlines general information about the accounting education and identifies 16 different variables which are effective on success level.

SPSS is utilized in analyzing the questionnaire.

Keywords: Accounting Lesson, Accounting Education, Factors Affecting Success.

Jel Classification: M40, M49, A29.

\footnotetext{
*Ahmet Şerbetçi, Kahramanmaraş Sütçü İmam Üniversitesi, SBE, İşletme Anabilim Dalı, ahmserbetci@gmail.com

** Doç. Dr. Mahmut Yardımcıoğlu, Kahramanmaraş Sütçü İmam Üniversitesi, İİF, İşletme Bölümü, mahmutyardimcioglu@gmail.com
} 


\section{GİRiş}

Eğitim gelişmiş veya gelişmemiş tüm ülkeler için hayati önem teşkil eden temel ihtiyaçlardandır. Toplumlar her geçen gün eğitilmiş insan gücüne daha fazla gereksinim duymakla birlikte bu gücü daha verimli ve etkin bir hale getirebilmek için çeşitli yöntem ve çözüm önerileri türetmeyi amaçlayan çalı̧̧malar içerisinde bulunmaktadırlar. Toplumsal değişim ve gelişimin doğru ölçülerde yaşanabilmesi için eğitimde artan ve süreklilik arz eden bir kalite anlayışıyla hareket edilmesi zorunludur. Bireysel ve toplumsal başarı açısından eğitime gösterilen önem ve hassasiyetin niteliği çok önemlidir. Ülkelerin kalkınma plan ve politikaları eğitimsel büyüme kararları ve uygulamalarıyla daha anlamlı bir hal alarak başarılı sonuçlara ulaşmalarına sebep olacaktır.

Başarı için kişisel motivasyon kadar çevresel faktörlerde oldukça önemlidir. Bu konu başarının sadece bireyin kontrolünde olmadığını etkileşim içerisinde bulunduğu çevreninde katkısının olduğunu göstermektedir. Başarının temelinde eğitim kalitesi yer alırken başarıyı getiren tek faktörün yalnızca eğitim kalitesi olduğu düşünülmemeli sosyo-kültürel etkilerinde varlığı da göz önünde bulundurulmalıdır

Eğitim hayatının bir bölümü olan akademik öğrenim sürecinde başarıyı elde etmek ve sürekli kılmak için gerekli faktörler belirlenmeli ve motivasyon kaynaklarıda desteklenmelidir. Bu çalışma muhasebe eğitiminin önemini ifade etmeyi ve muhasebe dersi için öğrencilerin başarılarına etki eden faktörlerin ve motivasyon kaynaklarının belirlenmesini amaçlamaktadır.

\section{MUHASEBE EĞİTIMININ TANIMI VE ÖNEMI}

Günümüz dünyasında işletmelerin faaliyet gösterdikleri çevrede çok önemli değişiklikler yaşanmakta ve yaşanmaya devam etmektedir. İşletmelerin yaşadığı bu değişimlere neden olan değişim unsurları teknoloji, küreselleşme ve pazarın yatırım odaklı almasıdır. Bu unsurların sonucunda artan rekabet ortamı ve ucuz bilginin ortaya çıkması, yeni endüstriler, karmaşıklaşan piyasa işlemleri ve finansal raporlamada değişiklik durumlarını gündeme getirmiştir.

İş dünyasında yaşanan değişimler, işletmelerin en önemli varlığı olan insan gücünün değerini artmakta ve muhasebe meslek mensuplarının da rollerinin değişmesi ve yeniden belirlenmesi gerekliliği ortaya çıkmaktadır. İşletme fonksiyonlarının bir bütün olarak belirtilen bu değişim sürecinden etkilenmesinin yanı sıra, yetişmiş insan gücü ve bilgisine dayanan muhasebe fonksiyonu da bu değişimin etkilerinin en fazla olarak yaşandığı alanlardan birisidir (Yürekli ve Gönen, 2015:303).

Muhasebe eğitiminin global düzeyde yapılması; bilgiye en kısa sürede ulaşabilen, ulaştığı bilgiyi üretime yansitabilen ve değişimin gerçekleşmesinde kullanılabilen, değişen dünya koşullarına her an uyum sağlayabilen, bilinmeyeni bulup onu dünya insanlarının 
ihtiyaçlarına sunabilen, riske girebilen, karar verdiğinde kararına sahip çıkabilen, sorun değil çözüm üreten, soru sormaktan, cevap vermekten, düşüncelerini söylemekten çekinmeyen, dinleme becerisi gelişmiş insan gücünün yetiştirilmesine bağlıdır (Ayboğa, 2003:354).

Muhasebe mesleği, hem uygulama hem de teorik eğitimin bir arada düşünülüp, değerlendirildiği bir alandır. Amerikan Muhasebe Derneği (AAA) tarafından oluşturulan "Muhasebe Eğitimi Değişim Komitesi (The Accounting Education Change Committee: AECC)", tarafından yapılan bir araştırmada muhasebe alanında kariyer yapacak öğrencilerin; meslek hayatında bilgi ve beceri anlamında ne kadar kabul edilebilir olduklarına bakılmıştır. $\mathrm{Bu}$ çalışma sonucunda; yalnızca üniversite eğitimlerinde kendilerini geliştirmek için değil, muhasebe alanında kariyer yapmak için gerekli bilgi ve becerilerin muhasebe programlarında mevcut olması gerektiği verisi elde edilmiştir. Muhasebe bilgi ve becerilerinin yanı sıra kişiler arası düşünsel beceriler, iletişim becerileri, etkili yazma, dinleme, sorunları tespit edip çözebilme becerilerine de ayrıca sahip olunması gereği araştırmanın diğer bir bulgusudur (Kutlu ve Öztürk, 2015:3).

Muhasebe eğitiminin en özellikli yönlerinden birisi de, muhasebe mantı̆̆ının ve uygulamalarının yasayla belirlenen standartlara ve normlara dayandırılmış olmasıdır (Bilginer, 1999: 115, akt. Çukacı ve Elagöz, 2006:148). Muhasebe uygulamalarına yön veren yasalar ülkemizde sık sık değişikliğe uğramaktadır. Muhasebe eğitiminin etkinliği açısından, muhasebe uygulamaları ile ilgili yasal değişikliklerin öğrencilere zamanında aktarılması gerekir. "Burada en önemli rol öğretim elemanına düşmektedir. Öğretim elemanının güncel değişiklikleri takip etmesi, mesleki bilgisinin yeterliliği ve sunum kalitesi çok önemlidir. Muhasebe eğitiminde öğrenci, anlayamadığı veya eksik bilgisini ya öğretim elemanından ya da kendi çabalarıyla tamamlayacaktır" (Demirkan, 2001: 55, akt. Çukacı ve Elagöz, 2006:148).

\section{MUHASEBE EĞİTiMININ AMACI}

Küreselleşen dünyada, muhasebeden sağlanan verilere gereksinim günden güne artmış ve muhasebe, ekonomik hayat için daha önemi bir hale gelmiştir. İşletmeyle ilgili taraflar, ülke sınırları içinde kalmayıp, ülke sınırlarını aşmış, muhasebe biriminden üretilen bilgilerle uluslararası düzeyde de ilgilenilir duruma gelinmiştir. İlgili taraflar doğru, güvenilir, zamanlı ve karşılaştırılabilir muhasebe bilgileri talep etmektedirler. Buna bağlı olarak, işletmeyle ilgili tarafların gereksinim duyduğu bilgileri üretecek muhasebe meslek elemanlarının, sürekli güncel bilgi ve becerilerle donatılması, geliştirilmesi ve yetiştirilmesi önem kazanmaktadır (Özkan ve Aksoy, 2015:285).

Günümüzde teknolojideki hızlı değişim işletmeleri, muhasebe mesleğini ve dolayısıyla muhasebe eğitimini etkilemektedir. İşletmelerdeki gelişmeler muhasebenin yeniden yapılandırılmasını, hedef, araç ve uygulamalarının yeniden şekillendirilmesini gerektirmektedir. Teknolojiden önemli ölçüde etkilenen işletmelerde muhasebeciden sadece 
defter tutma ya da rapor hazırlama istenmemektedir. İşletmelerde ileri teknolojilerin kullanılması özellikle proje yönetimi, risk yönetimi, bilgi yönetimi, zaman yönetimi, stratejik planlama, ulusal ve uluslararası pazarlama ve iletişim, e-ticaret, insan kaynakları yönetimi, üretim yönetimi, maliyet muhasebesi, denetim ve yönetim muhasebesi uygulamalarında önemli değişiklikler gerektirmektedir. Bu bakımdan muhasebe mesleğini yürütenlerin iyi bir mali analiz uzmanı, iyi bir girişimci, iyi bir pazarlamacı, iyi bir yönetici, iyi bir haberleşme uzmanı ve iyi bir halkla ilişskiler uzmanı olarak yetiştirilmesi gerekir. Bu bağlamda muhasebe eğitiminin hedefi, muhasebe temel kavram ve ilkelerini öğrenciye kazandırarak; öğrencilerin bilgiyi oluşturması, ölçmesi ve en önemlisi analiz ederek karar almada kullanmasının sağlanması olmalıdır (Dursun, 2006:17-18).

Küreselleşmeyle birlikte yaşanan liberalizasyonla işletmelerin mali tablolarının şeffaflı̆̆g, karşılaştırabilirliği ve herkes tarafından yorumlanabilmesi için 2005 yılından itibaren işletmeler tarafından uygulanması zorunla hale getirilen Uluslararası Muhasebe Standartları/Uluslararası Finansal Raporlama Standartları (IAS/IFRS) ile birlikte muhasebe bilgi sisteminin önemi daha da artmıştır. Özellikle yaşanan Enron olayı ve bu olayın yansımaları işletme yönetiminden, muhasebeye, denetime, raporlamaya ve muhasebe standartlarına kadar birçok alanı kalitenin artırılması açısından olumlu olarak etkilemiştir.

Muhasebe salt kayıt sistemi veya vergi yasaları çerçevesinde bilgi hazırlayan bir sistem olarak düşünülmemelidir. Muhasebe işletmenin içinde bulunduğu çevredeki değişimlerden doğrudan etkilenen ve kendini sürekli güncelleyen bir bilgi sistemidir. $\mathrm{Bu}$ bütün içinde yalnızca muhasebe bilgisi yeterli olmayıp, iktisat, maliye, hukuk, işletmecilik gibi bilgilerle muhasebecilerin donanması gerekmektedir. $\mathrm{Bu}$ nedenle muhasebe eğitimin amacı muhasebe bilgisinin kazandırılmasının yanı sıra, bu bilgileri yorumlama, analiz etme ve karar almada kullanmasına yardımcı olacak diğer disiplinlerden faydalanmaktır.

Hazırlanacak ders programlarında muhasebe eğitiminin amacı doğrultusunda, iktisat, hukuk, maliye, işletmecilik, matematik, edebiyat, müzik ve tiyatro gibi genel eğitim derslerine muhasebe dersleri kadar yer verilmelidir. Aksi takdirde muhasebe eğitimi almış öğrenciler, işletmelerin ihtiyacını karşılamada yetersiz kalacak ve finans ve mühendislik gibi alanların bu boşluğu doldurmasına neden olacaktır (Zaif ve Ayanoğlu, 2007:117).

\section{TÜRKIYYE'DE MUHASEBE EĞITIMININ TARIHHEL GELIŞIMI}

Tarihte en önemli ilk Türk devlet olarak sayılan Selçuklu Devleti, muhasebe tarihinde, vakıflar ve buna bağlı olarak Vakıf Muhasebesi'nin gelişimi açısından önemli bir yer tutmaktadır. Selçuklu ve Osmanlı devrinde ekonomik hayat, sistem bakımından birbirinin uzantısıdır. Devlet gelirlerinin büyük kısmı, toprak ürünlerinden ayni olarak tahsil edilen "Aşar vergisi” ile ticari emtiadan tahsil edilen "Öşür” ile sağlanmıştır. Osmanlı döneminde, maliye teşkilatı ilk olarak I. Murat döneminde kurulmuştur. Devlet ve orduya ait kayıtlar sadrazam ve defterdarın nezaretindeki "Vak-a Nüvis"lerce kayıt altına alınmıştır. Mali 
sisteme ilişkin ilk yazılı kanun; Fatih Sultan Mehmet döneminde gerçekleştirilmiştir. Bu döneme kadar yazılı olmadığı halde uygulanan kanunlar 2. Mehmet zamanında "Ecdat Kanunları" olarak bir araya getirilmiş, Kanuni Sultan Süleyman zamanında ise ilave kanunlar çıkartılmıştır (Tekşen vd., 2010:101).

Osmanlı Devleti döneminde ilk muhasebe öğretim okulu 1836-1839 yılında açılan Bâb-1 Defterdârî Mektebi'dir. Maliye memurlarının eğitim gördüğü bir okul olan Bab-1 Defterdari mektebi başlangıçta bir okul niteliğinde değildi fakat Fazlı Paşa Sarayının bir odası bu memurların eğitimi için kullanılmaktaydı. Burada daha çok hesap tutma hakkında eğitim verilmekteydi. Tanzimat'tan sonra Maliye memurlarından olan kalem kâtipleri için Maliye Nezareti içinde dershane tarzında eğitim verildiği ve bu eğitimle memurların Fransızcaya vakıf oldukları ve Fenn-i Cedid-iDefterî'de kendilerini geliştirdikleri ifade edilmektedir (Özkul, 2012:233).

1860'lı yıllara kadar muhasebe uygulamaları, batının kayıt yöntemine benzemeyen, Osmanlının kendine özgü muhasebe düzenine göre yürütülmüştür. Çift yanlı kayıt yöntemi ile tanışma XIX. Yüzyılın ikinci yarısında olmuş ve Osmanlı bu dönemde çift taraflı kayıt yöntemine uyum sağlamak durumunda kalmıştır. Bu durum muhasebe eğitiminde de etkisini göstermiş, 1860'l1 yıllara kadar Türk okullarının eğitim programlarında muhasebe dersi yer almamıştır ve muhasebe öğreti kitabı bulunmamaktadır. Bu dönemde muhasebe eğitimi yabancı okulların, özellikle Ermeni okullarının ders programlarında yer almış, muhasebe öğreti kitapları Ermeni asıllı yazarlar tarafından hazırlanmıştır. Çift yanlı kayıt yöntemine ilişkin Osmanlı Devleti'nde ilk kitaplar, Ermenice olarak hazırlanmış olup, 1828 ve 1830 yı1larında basılmıştır. Daha sonra 1853-1928 yılları arasında Fransızcadan tercüme edilen yaklaşık kırk kadar Türkçe muhasebe kitabına rastlanmaktadır. Fransızca kaynakların etkinliği uzun süre devam etmiştir. Fransız kültürü ağırlıklı muhasebe öğretiminin XIX. yüzyılın ilk yarısı ortalarından, XX.yüzyılın ortalarına kadar yaklaşık yüz yıl boyunca devam ettiği ileri sürülebilir. Bunun nedeni, XIX. yüzyıl ortalarına doğru Tanzimat sonrasında, sayısı 200'ü bulan Türk gencinin Fransa'ya gönderilmesi ve Paris'te bir Osmanlı okulunun açılması, XIX. Yüzyılın ikinci yarısı başlarında Türkiye'ye dönen bu Türk aydınlarının hem yönetimde etkili olmaları hem de Fransız muhasebe kitaplarını ve muhasebe öğretisini Türkiye’ye getirmeleridir. Çift yanlı kayıt yöntemi, dünya standartlarına uygun olarak XIX. yüzyılın ikinci yarısında Türkiye’ye bu şekilde gelebilmiştir (Gücenme Gençoğlu, 2009:32-32).

1926-1960 döneminde Türkiye'de çağdaş anlamda üniversitelerin kurulduğu dönemdir. Alman ekolünün muhasebe eğitimi üzerinde etkisi bulunmaktadır. Bu dönemde üniversiteler içinde muhasebe eğitimi veren kürsüler oluşturulmuş ve muhasebe eğitiminin kapsamı genişletilmiştir. Bu dönemde yüksekokullarda ve üniversitelerde muhasebe eğitimine yer verilmektedir. 1960 ve sonraki dönemlerde Amerikan ve İngiliz ekolünün etkili olduğu bir dönemdir. Bu dönemin en belirgin özelliği muhasebeyi kurala bağlama çalışmalarında hesap planlarına yer verilmiş olmasıdır. Muhasebe eğitimi ve buna bağlı olarak muhasebe 
uygulamaları açısından önemli gelişmelerin olduğu bir dönemdir. Bu dönemde Kamu İktisadi Teşekkülleri Tekdüzen Muhasebe Sistemi benimsenmiştir, 1971 yılında uygulamaya konulmuştur. Ayrıca Sermaye Piyasası kapsamındaki ortaklıklar için 1983 yılında Standart genel Hesap Planı, 1986 yılında bankacılık için Tekdüzen Hesap Planı ve 1994 yılında tüm işletmeler için Tekdüzen Hesap Planı uygulamaya konulmuştur (Şengel, 2010:82-83).

Ayrıca 1980'lerde muhasebe eğitim sürecinde etik eğitimi konuları da tartışılmaya başlamıştır. 1989 yılında yürürlüğe giren 3568 sayılı Meslek Kanunu, muhasebe mesleğinin hukukunu oluşturmakta ve 3568 Sayılı Meslek Kanunu ile yeni bir döneme giren muhasebecilik mesleğinin, kurumsallaşma süreci bir ölçüde muhasebe eğitimini de etkilemiştir.

Genel anlamda muhasebe standartları, muhasebe uygulamalarına yön veren ve finansal tabloların hazırlanmasına düzen getiren normlardır(Akgül ve Akay,2006:4). Finansal tabloların karşılaştırılabilir olması ve gerçeği yansıtması amacıyla muhasebe standartları oluşturulmuştur. 2005 tarihinden sonra yürürlüğe girmiştir.

2013 de yürürlüğe giren 6102 sayılı Türk Ticaret kanunu ile muhasebe standartlarının uygulanması zorunlu hale getirilirken bu olgu muhasebe eğitimine de yansımıştır (Güney, 2015:82).

\section{KONUYLA İLGILİ LITERATÜR İNCELEMESI}

Bugüne kadar, muhasebe dersi alan öğrencilerin muhasebe eğitimlerinin değerlendirilmesine yönelik birçok araştırma yapılmıştır. Yapılan bu araştırmalardan bazılarına göre;

Demir ve Çam (2006), "Muhasebe Bölümü Öğrencilerinin Muhasebe Öğreniminde Başarılarını Olumsuz Etkileyen Faktörlere İlişkin Bir Araştırma" isimli makalelerinde muhasebe öğreniminde başarıyı olumsuz etkileyen faktörler olarak "Dersin, her öğrencinin temel muhasebe bilgisine sahip olduğu düşüncesi ile işlenmesi, Muhasebe bilgi temelinin yetersiz oluşu, Sınavsız geçiş sistemi sebebiyle sınıfta bölümle (meslekle) ilgili hedef birliğinin kaybolması, Muhasebe derslerinin uygulama üzerinde gösterilmemesi, Öğretim elemanlarının dersleri monoton olarak anlatması, Muhasebedeki olayların bir bütün olarak kavranamaması, Hesapların temel işleyiş mantığının kavranamaması, Etkili öğrenme yöntemlerinin bilinmemesi, Verilen teorik bilginin iş bulmada etkili olmayacağı düşüncesi, Konuya ilişkin örnek sayısının az verilmesi, Derslere düzenli olarak devam edilmemesi, Başarılı olunamayacağı düşüncesi, Muhasebe mesleğine ilgi duyulmaması, MYO’ya YOK düzenlemesi sebebiyle zorunlu olarak gelinmesi, Bölümle ilgili geleceğe yönelik bir hedefin olmaması" değişkenlerini tespit etmişlerdir.

Tekşen, Tekin ve Gençtürk (2010), "Muhasebe Eğitiminin Değerlendirilmesi: Mehmet Akif Ersoy Üniversitesi’ne Bağlı Meslek Yüksek Okulları Öğrencileri Üzerine Bir Araştırma” 
isimli çalışmalarında muhasebe eğitimi üzerinde öğrencilerin haftada 4 saat olarak almış oldukları genel muhasebe dersinde verilen eğitimin kalitesinin daha da arttırılmasının gerekli olduğu tespit edilmiştir. Gelecekte öğrencileri için her alanda ihtiyaç olacak muhasebe ders sayının artırılması ve derslerde aktarılan bilgilerin mesleğe ilişkin temel bilgileri öğretme açısından daha da yeterli hale getirilmesinin gerekliliği belirtilmiştir. Bunun da gerek muhasebe eğitimi açısından gerekse de muhasebe mesleğinin kalitesi açısından başarıyı artıracağı açıklanmıştır.

Tuğay (2014), "Muhasebe Dersi Alan Öğrencilerin Muhasebe dersine Yönelik Algıları ve Muhasebe Öğretim Elemanlarından Beklentileri Üzerine Mehmet Akif Ersoy Üniversitesinde Bir Araştırma" isimli makalesinde yapılan araştırmada öğrencilerin büyük bir çoğunluğunun lisede muhasebe dersini almadığı, muhasebe derslerinde orta derecede zorlandıkları, muhasebe dersini en iyi anlama yönteminin tahtada açıklama yöntemi olduğu sonucu ortaya çıkmıştır. Ayrıca öğrencilerin, özellikle teknolojiyi kullanan, öğrencileriyle iyi iletişim kurabilen, öğretmeyi pekiştiren ve özellikle mesleki etik becerisine sahip, öğretim elemanlarını derslerinde görmek istedikleri tespit edilmiştir.

Kızıl ve Gencer (2016), "Muhasebe Dersi Alan Öğrencilerin Başarısına Etki Eden Faktörlerin Tespiti: Yalova Üniversitesi’nde Bir Uygulama” isimli çalışmalarında yapılan araştırma sonucu ticaret lisesi mezunlarının üniversitede muhasebe derslerinde daha başarılı olup olmadıkları hususunda kararsızlığın hakim olduğu görülmüştür. Ayrıca üniversitede iyi bir çalışma ortamına sahip olmanın, öğretim elemanının dersi sevdirmesinin, uygulamaya yönelik işlemesinin ve öğretim elemanının derslere devam durumunun öğrenci başarısını artıracağı tespit edilmiştir. Buna karşın öğretim elemanının etkili öğretim yöntemlerini bilmemesi, not değerlendirmesinde adil olmaması, monoton ve sinirli ders işlemesi, muhasebe mantığının ilk derslerde oturmaması ve sınav sorularının açık ve anlaşılır olmaması durumunun öğrenci başarısını düşüreceği açıklanmıştır.

Yıldırım (2015), “Genel Muhasebe Dersi Alan Öğrencilerin Derse İlişkin Beklentileri ve Başarı Durumlarının Değerlendirilmesi” isimli makalesinde yapılan araştırma sonucunda elde edilen sonuçlara göre "öğrencilerin cinsiyete göre başarı, kariyer, ödül, zaman, merak veya zevkli, zor, sıkıc1, motivasyon, bilgi, eğitici ve puan ortalaması arasında bir farklılık bulunmamıştır. Ancak, öğrencilerin bekledikleri ve aldıkları ders notları bakımından kadın öğrenciler lehine anlamlı bir fark bulunmuştur.

\section{MUHASEBE DERSINDE BAŞARIYI ETKILEYEN FAKTÖRLER: İSTATISTIKKSEL INCELEME}

\subsection{Problemin Tanımlanması}

$\mathrm{Bu}$ çalışmada muhasebe dersinde başarıyı etkileyen faktörler üzerinde, sosyodemografik karakteristiklerin, öğrencilerin alınmış olan Genel Muhasebe-1 dersiyle ilgili 
mevcut durumlarının ve düşüncelerinin, muhasebe dersi ile ilgili başarıyı etkileyebileceği düşünülen unsurların, öğrenciler ve öğretim elemanları ile ilgili faktörlerin araştırılması ve belirlenmesi amaçlanmıştır. Çalışmanın genel amacı muhasebe dersine ilişkin başarıyı etkileyen faktörlerin belirlenmesi ve elde edilen sonuca bağlı olarak bu faktörler ile ilgili çalışmalar yapılarak bireylerin akademik eğitim kalitesinin daha fazla iyileştirilmesine katkı sağlamaktır.

\subsection{Değiş̧kenlerin Belirlenmesi}

Muhasebe dersi ile ilgili başarıyı etkileyen faktörleri ölçmek için 63 adet açıklayıcı değişken belirlenmiş̧ir. Bağımlı değişken Genel Muhasebe-1 dersini almış, birinci sınıf (İkinci Öğretim) öğrencilerine ve aynı dersten tekrara kalan (İkinci Öğretim) öğrencilere sorulan "Dersten Aldığınız Harf Notu Nedir?" sorusudur. Fakültede "FF ve FD" harf notları başarısız, "'DD ve DC" harf notları şartlı başarılı, "CC, CB, BB, BA ve AA" harf notları ise başarılı olarak değerlendirilmektedir.

Açıklayıcı değişkenler, öğrencilerin sosyo-demografik özellikleri, öğrencilerin almış oldukları Genel Muhasebe-1 dersiyle ilgili mevcut durumları ve düşünceleri ile muhasebe dersiyle ilgili başarıyı etkileyebileceği düşünülen faktörlerden oluşmaktadır. Muhasebe dersiyle ilgili başarıyı etkileyebilecek faktörler; dersler ile ilgili, öğrenciler ile ilgili ve öğretim elemanları ile ilgili olmak üzere üç bölümden oluşmaktadır. Açıklayıcı değişkenlerin ve bölümlerin belirlenmesinde fakülte öğretim elemanları ve uzmanlarla yapılan görüşmeler sonucu elde edilmiş bilgiler ile deneyimlerden yararlanılmıştır.

\subsection{Yöntem}

\subsubsection{Araştırma Örnekleminin Belirlenmesi}

Araştırma örneklemi iki aşamada seçilmiştir. İlk etapta araştırma ana kütlesi olarak Kahramanmaraş Sütçü İmam Üniversitesi İktisadi ve İdari Bilimler Fakültesi belirlenmiştir. İkinci etapta ise Genel Muhasebe-1 dersini almış birinci sınıf (İkinci Öğretim) öğrencileri ve aynı dersten tekrara kalan (İkinci Öğretim) öğrenciler başarı düzeylerinden dolayı uygulama için örneklem olarak seçilmiştir.

Genel Muhasebe-1 dersini almış, birinci sınıf (İkinci Öğretim) ve aynı dersten tekrara kalan (İkinci Öğretim) toplam öğrenci sayısı olan 180 anketin tamamı öğrenciler tarafindan cevaplanmıştır. Sonuç olarak çalışmada 180 adet anketten elde edilmiş olan veri setinden yararlanılmıştır.

\subsubsection{Anket Formunun Tasarımı ve Değişkenlerin Ölçülmesinde Kullanılan Ölçek Tipi}

Veri setini elde etmek için hazırlanmış olan anket kağıdı üç bölümden oluşmaktadır. İlk bölümde öğrencilerin sosyo-demografik karakteristiklerine ilişkin toplam dokuz soru 
bulunmaktadır. Anket kağıdının ikinci bölümünde öğrencilerin almış olduğu Genel Muhasebe-1 dersi ile ilgili mevcut durumlarına ve düşüncelerine ilişkin on soruya yer verilmiştir. Birinci ve ikinci bölümde genel olarak evet, hayır şeklinde ve kategorik cevaplara sahip sorular bulunmaktadır. Üçüncü bölümde ise muhasebe dersinde başarıyı etkileyebileceği düşünülmüş kırkdört faktör üç başlık altında beşli likert ölçeği kullanılarak verilmiştir. Birici bölümde dersler ile ilgili faktörler, ikinci bölümde öğrenciler ile ilgili faktörler ve üçüncü bölümde ise öğretim elemanları ile ilgili faktörlere yer verilmiştir. Üçüncü bölümde kullanılan likert ölçeği "Kesinlikle Etkisizdir, Etkisizdir, Kararsızım, Etkilidir ve Kesinlikle Etkilidir" ifadeleriyle kullanılmıştır.

Anket Genel Muhasebe-1 dersini almış olan birinci sınıf (İkinci Öğretim) öğrencilerine ve aynı dersten tekrara kalan (İkinci Öğretim) toplam 180 öğrenciye birçok kez uygulanarak test edilmiştir. Test tekrar test yöntemi, soruların uzunluğunun ve cevaplayıcıların anlayacağı biçimde uygun ifadelerin belirlenmesi ve soruların uygun sırada sorulması için uygulanmıştır. Geliştirilen ölçeklerin güvenilirlik düzeyini saptamak için tutarlılığın ölçütü olan Cronbach $\alpha$ katsayısı 0,90 olarak bulunmuştur. Bu değer ölçekte bulunan maddelerin yüksek oranda birbirleriyle tutarlı ve aynı özelliğin öğelerini ölçen maddeler olduğunu göstermektedir.

\subsection{Veri Analizi}

$\mathrm{Bu}$ çalışmada tüm analizler SPSS 16.0 paket programı kullanılarak yürütülmüştür. Ankette kullanılan ölçeklerin güvenilirliği ve tutarlılığının belirlenmesi için Cronbach tarafından geliştirilmiş $\alpha$ katsayısı kullanılmıştır.

Muhasebe dersinde başarıyı etkileyebileceği düşünülmüş unsurlar ile sosyodemografik faktörler ve alınmış olan Genel Muhasebe-1 dersiyle ilgili mevcut durum ve düşünceler arasındaki ilişkiyi modellemek için Sıralı Lojistik Regresyon tekniği kullanılmıştır. Sıralı Lojistik Regresyon analizinin temelinde bağlantı fonksiyonları yer almaktadır. Bu bağlantı fonksiyonları kullanılarak Sıralı Lojistik Regresyon modeli geliştirilmiştir. Alınmış olan Genel Muhasebe-1 dersiyle ilgili mevcut durum ve düşünceler, sosyo-demeografik faktörler ve muhasebe dersinde başarıyı etkileyebileceği düşünülmüş unsurlar için betimleyici istatistikler elde edilmiştir. Ayrıca paralel eğriler varsayımının geçerliliğinin test edilmesi için ki-kare değerinden yararlanılmıştır. Kurulan modelin uygunluğunun test edilmesi ve verideki değişkenliği açıklamak için sözde $R^{2}$ modele uygunluk testleri kullanılmıştır.

\subsection{Uygulama}

Belirlenen Genel Muhasebe-1 dersini almış, birinci sınıf (İkinci Öğretim) öğrencileri ve aynı dersten tekrara kalan (İkinci Öğretim) öğrencilere uygulanan 180 anketten elde edilen veri setine ait sosyo-demografik betimleyici değişkenler aşağıda verilmiştir. Yapılan 
araştırmada öğrencilerin \%41,1'i bayan, $\% 58,9$ 'u baydır. Veri setinden elde edilen sonuçlara göre öğrencilerin yaş ortalaması 21 olarak bulunmuştur. Öğrencilerin mezun oldukları lise türü incelendiğinde \%48,9'unun normal lise, \%0,6'sının süper lise, \%31,7'sinin anadolu lisesi, \%7,8'inin özel lise, \%11,1'inin ise diğer liselerden mezun oldukları görülmüştür. Öğrencilerin mezun oldukları lisedeki bölümleri incelendiğinde \%76,1'inin eşit ağırlık, \%23,9'unun ise sayısal çıkışlı oldukları görülmüştür. Öğrencilere öğrenim gördükleri sınıf sorulduğunda $\% 40,6$ 'sı birinci sınıf, $\% 23,9$ 'u ikinci sınıf, $\% 18,9$ 'u üçüncü sınıf, $\% 11,1$ 'i dördüncü sınıf, $\% 11,1$ 'i ise fakülteyi dört senelik süreyi aşarak uzatmış olduklarını belirtmişlerdir. Öğrencilere öğrenim gördükleri bölümü isteyerek mi seçtikleri sorulduğunda \%60'ının evet, \%40'ının hayır olarak cevap verdiği görülmüştür. Öğrencilere dersin alınış şekli sorulduğunda $\% 43,9$ 'u ilk ve $\% 56,1$ 'i tekrar olarak belirtmiş̧ir. Derse ilgi duyuyor musunuz sorusuna öğrencilerin \%67,2'si evet, \%32,8'i hayır olarak cevap verdiği görülmüştür. Dersi sunan öğretim elemanını ders hakkında yeterli buluyor musunuz sorusuna öğrencilerin $\% 88,9$ 'u evet, \%11,1'i hayır şeklinde cevap vermiştir. Ders için öğretim elemanının yararlanmanızı istediği kaynağı anlaş1ır buluyor musunuz sorusuna öğrencilerin \%75,6's1 evet, \%24,4'ü hayır olarak cevap vermiştir. Fakültenizde ders hakkında yeterli bilgi verildiğini düşünüyor musunuz sorusunu öğrencilerin $\% 54,4$ 'ü evet, $\% 45,6$ 'sı hayır olarak yanıtlamıştır. Günlük ders tekrarı yapar mısınız sorusuna öğrencilerin \%22,2'si evet, \%77,8'i hayır şeklinde cevaplamıştır. Öğrencilerin Genel Muhasebe-1 dersi için haftalık ayırdıkları vaktin ortalaması 4,6 saat olarak bulunmuştur. Dersi anlama ve öğrenme konusunda birilerinin yardımına ihtiyaç duydunuz mu sorusuna öğrencilerin \%75,6's1 evet, \%24,4'ü hayır olarak cevaplamıştır. Derste edindiğiniz bilgileri üniversite yaşantınız haricinde kullanacağınız düşünüyor musunuz sorusunu öğrencilerin $\% 63,3$ 'ü evet, \%36,7'si hayır şeklinde yanıtlamıştır. 
Tablo 1. Betimleyici Değişkenler (Sosyo-Demografik Değişkenler)

\begin{tabular}{|c|c|c|c|}
\hline & & $\mathrm{N}$ & $\%$ \\
\hline \multirow[t]{9}{*}{ Dersten Aldığınız Harf Notu Nedir } & AA & 6 & $3,3 \%$ \\
\hline & BA & 6 & $3,3 \%$ \\
\hline & BB & 5 & $2,8 \%$ \\
\hline & $\mathrm{CB}$ & 6 & $3,3 \%$ \\
\hline & $\mathrm{CC}$ & 18 & $10,0 \%$ \\
\hline & DC & 16 & $8,9 \%$ \\
\hline & DD & 13 & $7,2 \%$ \\
\hline & FD & 9 & $5,0 \%$ \\
\hline & FF & 101 & $56,1 \%$ \\
\hline \multirow[t]{2}{*}{ Cinsiyetiniz } & Bayan & 74 & $41,1 \%$ \\
\hline & Bay & 106 & $58,9 \%$ \\
\hline \multirow[t]{11}{*}{ Yaşınız } & 18 & 2 & $1,1 \%$ \\
\hline & 19 & 27 & $15,0 \%$ \\
\hline & 20 & 41 & $22,8 \%$ \\
\hline & 21 & 43 & $23,9 \%$ \\
\hline & 22 & 34 & $18,9 \%$ \\
\hline & 23 & 19 & $10,6 \%$ \\
\hline & 24 & 8 & $4,4 \%$ \\
\hline & 25 & 2 & $1,1 \%$ \\
\hline & 26 & 1 & $6 \%$ \\
\hline & 27 & 2 & $1,1 \%$ \\
\hline & 28 & 1 &, $6 \%$ \\
\hline \multirow[t]{5}{*}{ Mezun Olduğunuz Lisenin Türü } & Normal Lise & 88 & $48,9 \%$ \\
\hline & Süper Lise & 1 &, $6 \%$ \\
\hline & Anadolu Lisesi & 57 & $31,7 \%$ \\
\hline & Özel Lise & 14 & $7,8 \%$ \\
\hline & Diğer Liseler & 20 & $11,1 \%$ \\
\hline \multirow[t]{2}{*}{ Mezun Olduğunuz Lisedeki Bölümünüz } & Eşit Ağarlık & 137 & $76,1 \%$ \\
\hline & Sayısal & 43 & $23,9 \%$ \\
\hline \multirow[t]{5}{*}{ |Öğrenim Gördüğünüz Sınıf } & 1 & 73 & $40,6 \%$ \\
\hline & 2 & 43 & $23,9 \%$ \\
\hline & 3 & 34 & $18,9 \%$ \\
\hline & 4 & 20 & $11,1 \%$ \\
\hline & $4+x$ & 10 & $5,6 \%$ \\
\hline \multirow[t]{2}{*}{ Öğrenim Gördüğünüz Bölümü İsteyerek mi Seçtiniz } & Evet & 108 & $60,0 \%$ \\
\hline & Hayır & 72 & $40,0 \%$ \\
\hline \multirow[t]{2}{*}{ Barındığınız Yerde Uygun Ders Çalışma Ortamı Var mı } & Evet & 149 & $82,8 \%$ \\
\hline & Hayır & 31 & $17,2 \%$ \\
\hline \multirow[t]{5}{*}{ Not Ortalamanız Hangi Aralıktadır } & $\leq 1.5$ & 43 & $23,9 \%$ \\
\hline & $1.6-2.0$ & 85 & $47,2 \%$ \\
\hline & $2.1-2.5$ & 41 & $22,8 \%$ \\
\hline & $2.6-3.0$ & 8 & $4,4 \%$ \\
\hline & $3.1-3.5$ & 3 & $1,7 \%$ \\
\hline
\end{tabular}


Tablo 2. Betimleyici Değişkeler (Genel Muhasebe-1 Dersi İle İlgili Mevcut Durum ve Düşünceler)

\begin{tabular}{|c|c|c|c|}
\hline \multirow[t]{2}{*}{ Dersin Alınış Şekli } & Tilk & 79 & $43,9 \%$ \\
\hline & Tekrar & 101 & $56,1 \%$ \\
\hline \multirow[t]{2}{*}{ Derse İlgi Duyuyor musunuz } & Evet & 121 & $67,2 \%$ \\
\hline & Hayır & 59 & $32,8 \%$ \\
\hline \multirow{2}{*}{$\begin{array}{l}\text { Dersi Sunan Öğretim Elemanını Ders Hakkında Yeterli } \\
\text { Buluyor musunuz }\end{array}$} & Evet & 160 & $88,9 \%$ \\
\hline & Hayır & 20 & $11,1 \%$ \\
\hline \multirow{2}{*}{$\begin{array}{l}\text { Ders İçin Öğretim Elemanının Yararlanmanızı İstediği } \\
\text { Kaynağı Anlaşılır Buluyor musunuz }\end{array}$} & Evet & 136 & $75,6 \%$ \\
\hline & Hayır & 44 & $24,4 \%$ \\
\hline \multirow{2}{*}{$\begin{array}{l}\text { Fakültenizde Ders Hakkında Yeterli Bilgi Verildiğini } \\
\text { Düşünüyor musunuz }\end{array}$} & Evet & 98 & $54,4 \%$ \\
\hline & Hayır & 82 & $45,6 \%$ \\
\hline \multirow[t]{2}{*}{ Günlük Ders Tekrarı Yapar mısınız } & Evet & 40 & $22,2 \%$ \\
\hline & Hayır & 140 & $77,8 \%$ \\
\hline \multirow[t]{18}{*}{ Ders İçin Haftalık Ortalama Kaç Saat Vakit Ayııırsınız } & 0 & 27 & $15,0 \%$ \\
\hline & 1 & 27 & $15,0 \%$ \\
\hline & 2 & 29 & $16,1 \%$ \\
\hline & 3 & 20 & $11,1 \%$ \\
\hline & 4 & 13 & $7,2 \%$ \\
\hline & 5 & 23 & $12,8 \%$ \\
\hline & 6 & 4 & $2,2 \%$ \\
\hline & 7 & 6 & $3,3 \%$ \\
\hline & 8 & 4 & $2,2 \%$ \\
\hline & 9 & 1 &, $6 \%$ \\
\hline & 10 & 9 & $5,0 \%$ \\
\hline & 12 & 2 & $1,1 \%$ \\
\hline & 14 & 1 &, $6 \%$ \\
\hline & 15 & 4 & $2,2 \%$ \\
\hline & 20 & 6 & $3,3 \%$ \\
\hline & 21 & 1 &, $6 \%$ \\
\hline & 25 & 1 &, $6 \%$ \\
\hline & 30 & 2 & $1,1 \%$ \\
\hline \multirow{2}{*}{$\begin{array}{l}\text { Dersi Anlama ve Öğrenme Konusunda Birilerinin Yardımına } \\
\text { İhtiyaç Duydunuz mu }\end{array}$} & Evet & 136 & $75,6 \%$ \\
\hline & Hayır & 44 & $24,4 \%$ \\
\hline \multirow[t]{2}{*}{ Dersi Hiç Başaramayacağınızı Düşündünüz mü } & Evet & 120 & $66,7 \%$ \\
\hline & Hayır & 60 & $33,3 \%$ \\
\hline \multirow{2}{*}{$\begin{array}{l}\text { Derste Edindiğiniz Bilgileri Üniversite Yaşantınız Haricinde } \\
\text { Kullanacağınızı Düşünüyor musunuz }\end{array}$} & Evet & 114 & $63,3 \%$ \\
\hline & Hayır & 66 & $36,7 \%$ \\
\hline Valid & & 180 & $100,0 \%$ \\
\hline Missing & & 0 & \\
\hline Total & & 180 & \\
\hline
\end{tabular}


Sosyo-demografik karakteristikler, Genel Muhasebe-1 dersiyle ilgili mevcut durum ve düşünceler ile muhasebe dersindeki başarıyı etkileyen faktörleri belirlemek için Sıralı Lojistik Regresyon analizi kullanılmıştır. Cauchit, Complementary Log-log, Logit, Negative Log-log ve Probit olmak üzere beş bağlantı fonksiyonu kullanılarak Sıralı Lojistik Regresyon modelleri yapılandırılmıştır. Ancak uygulamada Probit haricindeki modellere uygun kriterleri yani paralel eğriler varsayımını sağlamadığı ve bu modellerin uygunluk testleri anlamsız sonuçlar verdiği için çalışmada yer verilmemiştir. Yapılandırılan modeller arasından uygulama için Probit bağlantı fonksiyonu kullanılarak elde edilen Siralı Lojistik Regresyon modeli, paralel eğriler varsayımını sağlamış ve modelin uygunluk testleri istatistiksel olarak anlamlı sonuçlar vermiştir.

\subsubsection{Muhasebe Dersinde Başarıyı Etkileyen Faktörlerin Analizi}

Genel Muhasebe-1 dersi için yapılmış Probit bağlantılı Sıralı Lojistik Regresyon Modeli için Paralel Eğriler varsayımı Tablo 3 de verilmiştir.

Tablo 3. Paralel Eğriler

\begin{tabular}{|l|c|c|c|c|}
\hline Model & -2 Log Likelihood & $X^{2}$ & s.d. & Olasilik \\
\hline Yokluk Hipotezi & 400,673 & & & \\
General & $223,408^{\mathrm{b}}$ & $177,265^{\mathrm{c}}$ & 441 & 1,000 \\
\hline
\end{tabular}

Bağlantı Fonksiyonu: Probit

$H_{0}=$ Parametre tahminleri aynı kesme noktasından geçer.

$H_{1}=$ Parametre tahminleri farklı kesme noktasından geçer

Paralellik varsayımı gereği parametrelerin tahmini değerlerinin bağımlı değişkenin tüm kategorileri için aynı kesme noktasından geçmeleri şartı bulunmaktadır. Paralellik varsayımı görüldüğü üzere Ki kare testi ile test edilmiştir. P olasılığı 1'dir. P>0,005 olduğu için de $H_{0}$ parametresi reddedilemez ve paralellik varsayımını sağladığı ifade edilebilir.

Tablo 4. Kİ-kare

\begin{tabular}{|l|c|c|c|}
\hline & $X^{2}$ & s.d. & Olasilik \\
\hline Pearson & 1357,129 & 1361 &, 525 \\
Sapma & 399,287 & 1361 & 1,000 \\
\hline
\end{tabular}

Bağlantı Fonksiyonu: Probit

$H_{0}=$ Model verileri itibariyle uygundur.

$H_{1}=$ Model verileri itibariyle uygun değildir.

Modelin uyum iyiliğinin incelenmesi konusunda Sapma ve Ki kare değerleri göz önünde bulundurulmalıdır. Tablo 4 de görüldüğü üzere bu test istatistiklerine ait olasılıklar 
0,05 'ten büyüktür. Dolayısıyla modelin verilerle uyum içinde olduğunu ifade eden $H_{0}$ hipotezi reddedilemez. Buda modelin uyum iyiliğinin sağlandığını gösterir.

Ek olarak bağımlı değişken "Dersten Aldığınız Harf Notu Nedir?" ile açıklayıcı değişkenler "sosyo-demografik karakteristikler, Genel Muhasebe-1 dersiyle ilgili mevcut durum ve düşünceler ile muhasebe dersinde başarıyı etkileyebileceği düşünülmüş faktörler" arasındaki ilişkinin gücünü ölçmek ve değerlendirmek için sözde $\mathrm{R}^{2}$ değerleri, Cox-snell $(0,937)$, Nagelkerke (1), McFadden (1) olarak bulunmuştur.

Tablo 5 de görüldüğü gibi modelde yer alan 16 açıklayıcı değişken olarak, sosyodemografik karakteristikler için "Öğrencilerin Not Ortalamasının Bulunduğu Aralık”, Genel Muhasebe-1 dersiyle ilgili mevcut durum ve düşünceler hakkında "Ders İçin Öğretim Elemanının Yararlanılmasını İstediği Kaynağın Anlaşı1ır Bulunması, Ders İçin Haftalık Ortalama Ayrılan Vakit, Dersi Anlama ve Öğrenme Konusunda Birilerinin Yardımına İhtiyaç Duyulması", muhasebe dersinde başarıyı etkileyebileceği düşünülmüş faktörler hakkında ders ile ilgili bölüm için "Dersin Yeterli Sayıda Örnek Problemler Dahilinde İşlenmesi, Konuların İşleniş Tarzı, Derste Verilen Bilgilerin İş Hayatıyla İlgili Güncel Bilgiler Olması, Ders Saatlerinin Erken Olması, Dersin Teori Kısmının Yanında Özgün Uygulamalarla Birlikte Verilmesi, Ders Hakkında Dersi Almış Öğrenciler Tarafindan Yapılan Yönlendirmeler", öğretim elemanı için "Konulara Hakim Olması, Tecrübeli Olması, Derste Zamanı Etkili ve Verimli Kullanması, Ders Süresince Öğrencilerle Etkileşimini Yitirmemesi, Dersi Sınıf Tahtasını Kullanarak İşlemesi, Dersi Slaytlar Yardımı İle İşlemesi” faktörleri anlamlı bulunmuştur.

Tahmin edilen parametre değeri istatistiksel olarak anlamlı ve pozitif işaretli olan Genel Muhasebe-1 dersiyle ilgili mevcut durum ve düşünceler hakkında "Ders İçin Öğretim Elemanının Yararlanılmasını İstediği Kaynağın Anlaşılır Bulunması", muhasebe dersinde başarıyı etkileyebileceği düşünülmüş faktörler hakkında ders ile ilgili bölüm için "Dersin Yeterli Sayıda Örnek Problemler Dahilinde İşlenmesi, Derste Verilen Bilgilerin İş Hayatıyla İlgili Güncel Bilgiler Olması, Ders Saatlerinin Erken Olması, Dersin Teori Kısmının Yanında Özgün Uygulamalarla Birlikte Verilmesi”, öğretim elemanıyla ilgili bölüm için "Konulara Hakim Olması, Derste Zamanı Etkili ve Verimli Kullanması, Dersi Sınıf Tahtasını Kullanarak İşlemesi" değişkenlerinin değeri bir birim artırıldığında "Dersten Alınan Harf Notu" düzeyinde parametre değeri kadar artışa neden olacaktır. 
Tablo 5. Parametre Tahminleri

\begin{tabular}{|c|c|c|c|c|c|c|}
\hline & & Tahminler & Std. Hata & Wald & s.d. & p \\
\hline \multirow{8}{*}{ 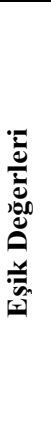 } & [Alınan Harf Notu= AA] & 3,165 & 3,061 & 1,069 & 1 & 301 \\
\hline & [Alınan Harf Notu =BA] & 3,836 & 3,058 & 1,574 & 1 & ,210 \\
\hline & [Alınan Harf Notu = BB] & 4,248 & 3,058 & 1,929 & 1 & ,165 \\
\hline & [Alınan Harf Notu = CB] & 4,599 & 3,060 & 2,259 & 1 & ,133 \\
\hline & [Alınan Harf Notu = CC] & 5,345 & 3,066 & 3,039 & 1 & 081 \\
\hline & [Alınan Harf Notu = DC] & 5,869 & 3,071 & 3,653 & 1 & ,056 \\
\hline & [Alınan Harf Notu = DD] & 6,240 & 3,074 & 4,120 & 1 & ,042 \\
\hline & [Alınan Harf Notu = FD] & 6,470 & 3,076 & 4,424 & 1 & ,035 \\
\hline \multirow{26}{*}{ 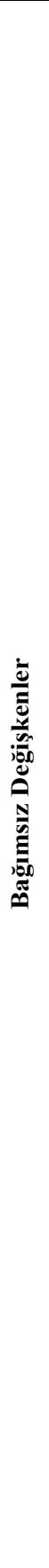 } & $\begin{array}{l}\text { Dersin ve Kaynak Kitapların Güncelliği ve } \\
\text { Anlaş1ırlığı }\end{array}$ &,- 005 & ,139 & ,002 & 1 & ,969 \\
\hline & $\begin{array}{l}\text { Mevcut Ders Kaynaklarının Başka Kaynaklarla } \\
\text { Desteklenmesi }\end{array}$ & ,248 & ,136 & 3,340 & 1 & ,068 \\
\hline & $\begin{array}{l}\text { Dersin Yeterli Sayıda Örnek Problemler } \\
\text { Dahilinde İşlenmesi }\end{array}$ & ,467 & ,179 & 6,817 & 1 & ,009 \\
\hline & Konular İçin Verilen Örneklerin Sayısı &,- 141 & , 172 & ,675 & 1 & ,411 \\
\hline & $\begin{array}{l}\text { Derste Verilen Örneklerin Öğrenim Gördüğünüz } \\
\text { Bölüm ile İlgili Olması }\end{array}$ & ,088 & ,167 & ,278 & 1 & ,598 \\
\hline & Konuların İşleniş Tarzı &,- 604 & ,202 & 8,950 & 1 &, 003 \\
\hline & Konular ile İlgili Verilen Ödevler &,- 031 & ,183 & ,029 & 1 & ,865 \\
\hline & $\begin{array}{l}\text { Derste Verilen Ödevlerin Mezuniyet Sonrası } \\
\text { Sinavlara Yönelik Olması }\end{array}$ &,- 111 & ,136 & ,673 & 1 & ,412 \\
\hline & $\begin{array}{l}\text { Derste Verilen Bilgilerin İş Hayatıyla İlgili } \\
\text { Güncel Bilgiler Olması }\end{array}$ & ,367 & ,148 & 6,116 & 1 &, 013 \\
\hline & Derste Teknolojik İmanlardan Yararlanılması & ,098 & ,121 & ,654 & 1 & ,419 \\
\hline & Öğrencilerin Grup Çalışmasına Özendirilmesi & 056 & ,126 & ,195 & 1 & ,659 \\
\hline & Sınav Sorularının İçeriği & ,141 & ,164 & ,744 & 1 & ,388 \\
\hline & Sinav Süresi &,- 032 & ,131 & ,059 & 1 & ,808 \\
\hline & Sinav Stilinin Klasik Olması &,- 072 & ,103 & ,487 & 1 & ,485 \\
\hline & Sinav Stilinin Test Olması & 151 & 097 & 2,417 & 1 & ,120 \\
\hline & $\begin{array}{l}\text { Sinavlarda Hesap Planı Kullanmanın Serbest } \\
\text { Olması }\end{array}$ &,- 172 & ,139 & 1,514 & 1 & ,219 \\
\hline & $\begin{array}{l}\text { Sinavlarda Kitap Kullanma Serbstliğinin } \\
\text { Tanınmas1 }\end{array}$ & ,078 & ,124 & 399 & 1 & ,528 \\
\hline & $\begin{array}{l}\text { Sinav Kağıtlarının Dersi Veren Öğretim Elemanı } \\
\text { Tarafından Değerlendirilmesi }\end{array}$ & ,157 & ,130 & 1,445 & 1 & ,229 \\
\hline & Ders Saatlerinin Erken Olması & ,245 & ,122 & 4,023 & 1 &, 045 \\
\hline & $\begin{array}{l}\text { Dersin Teori Kısmının Yanında Özgün } \\
\text { Uygulamalarla Birlikte Verilmesi }\end{array}$ &,- 449 & ,148 & 9,238 & 1 & ,002 \\
\hline & Dersteki Sinıf Mevcudu &, 114 & ,142 & ,645 & 1 & ,422 \\
\hline & $\begin{array}{l}\text { Ders Hakkında Dersi Almış Öğrenciler } \\
\text { Tarafından Yapılan Yönlendirmeler }\end{array}$ &,- 452 & ,129 & 12,345 & 1 &, 000 \\
\hline & Derslere Devam Durumu &,- 265 & ,153 & 3,004 & 1 & 083 \\
\hline & Derslere Aktif Katılımda Bulunulması & ,125 & ,151 & ,681 & 1 & ,409 \\
\hline & Günlük Ders Tekrarının Yapılması &,- 147 & ,153 & ,919 & 1 & ,338 \\
\hline & Derse Duyulan İlgi & ,122 & ,167 & ,537 & 1 & ,464 \\
\hline
\end{tabular}


Tablo 5. Parametre Tahminleri (Devamı)

\begin{tabular}{|c|c|c|c|c|c|c|}
\hline \multirow{36}{*}{ 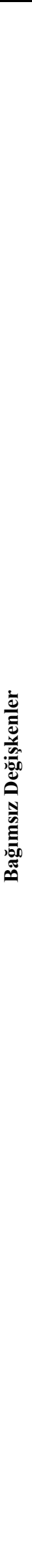 } & Derste Not Tutulmas 1 & 010 & ,162 & 004 & 1 & ,951 \\
\hline & Konulara Hakim Olması & ,670 & ,188 & 12,659 & 1 &, 000 \\
\hline & Konuları Daha anlaşılır Bir Biçimde İşlemesi &,- 128 & ,196 & ,424 & 1 &, 515 \\
\hline & Tecrübeli Olması &,- 512 & ,221 & 5,361 & 1 &, 021 \\
\hline & Derse Hazırlıklı Gelmesi &,- 435 & ,225 & 3,742 & 1 &, 053 \\
\hline & Öğretmeye Daha Hevesli Olması &,- 197 &, 177 & 1,230 & 1 & ,267 \\
\hline & Sinavlardaki Puanlandırma Tutumu & 013 &, 168 &, 006 & 1 & ,938 \\
\hline & Derste Zamanı Etkili ve Verimli Kullanması & ,402 &, 194 & 4,304 & 1 & ,038 \\
\hline & $\begin{array}{l}\text { Ders Süresince Öğrencilerle Etkileşimini } \\
\text { Yitirmemesi }\end{array}$ &,- 459 & ,198 & 5,395 & 1 & ,020 \\
\hline & Öğrencilerine Ders Haricinde de Vakit Ayırması & ,071 & ,174 &, 166 & 1 & ,684 \\
\hline & $\begin{array}{l}\text { Öğrenciler ile Arasında Olumlu Bir İletişimin } \\
\text { Olması }\end{array}$ & ,171 &, 186 & ,844 & 1 & ,358 \\
\hline & Öğrenciler ile Olan İlişkilerinde Tarafsız Olması & ,323 & ,195 & 2,752 & 1 & ,097 \\
\hline & Öğrencilerin Derse Aktif Katılımını Teşvik etmesi &,- 156 & ,206 &, 575 & 1 & ,448 \\
\hline & Dersi sınıf Tahtasını Kullanarak İşlemesi & ,496 &, $\mathbf{1 8 1}$ & 7,535 & 1 &, 006 \\
\hline & Dersi Slaytlar Yardımı ile İşlemesi &,- 440 &, 161 & 7,447 & 1 & ,006 \\
\hline & Daha akıcı Bir Hitabete Sahip Olması &,- 159 & ,189 & ,710 & 1 & ,399 \\
\hline & Sinıf Üzerindeki Otoritesi & 358 & ,188 & 3,617 & 1 &, 057 \\
\hline & Genç Olması &, 003 &, 120 &, 001 & 1 & ,978 \\
\hline & Cinsiyet & 164 & ,265 & 384 & 1 &, 535 \\
\hline & Yaş & 114 & , 107 & 1,136 & 1 & ,286 \\
\hline & Mezun Olunan Lisenin Türü & 004 & ,079 & ,002 & 1 & ,962 \\
\hline & Mezun Olunan Lisedeki Bölüm &, 047 & ,297 & ,025 & 1 & ,875 \\
\hline & Öğrenim Görülen Sınıf & 077 & ,186 & 174 & 1 & ,677 \\
\hline & Öğrenim Görülen Bölümün İsteyerek Seçilmesi & ,024 & ,289 &, 007 & 1 & ,934 \\
\hline & $\begin{array}{l}\text { Barınılan Yerde Uyun Ders Çalışma Ortamının } \\
\text { Olması }\end{array}$ &,- 034 & ,345 &, 010 & 1 & ,921 \\
\hline & Not Ortalaması &,- 769 & ,158 & 23,662 & 1 &, 000 \\
\hline & Dersin Alıış Şekli & 279 & ,365 & ,585 & 1 & ,444 \\
\hline & Derse Duyulan İlgi &,- 076 & ,331 & ,053 & 1 & ,819 \\
\hline & $\begin{array}{l}\text { Dersi Sunan Öğretim Elemanının Ders Hakında } \\
\text { Yeterli Olması }\end{array}$ &,- 159 & ,609 & ,068 & 1 & ,794 \\
\hline & $\begin{array}{l}\text { Ders İçin Öğretim Elemanının } \\
\text { Yararlanılmasının İstediği Kaynağın Anlaşılır } \\
\text { Bulunması }\end{array}$ & 1,099 & ,427 & 6,611 & 1 &, 010 \\
\hline & Fakültede Ders Hakkında Yeterli Bilgi Verilmesi & ,487 & ,264 & 3,406 & 1 & ,065 \\
\hline & Günlük Ders Tekrarının Yapılması &,- 294 & ,319 & ,854 & 1 & ,355 \\
\hline & Ders İçin Haftalık Ortalama Ayrılan Vakit &,- 060 &, 023 & 6,507 & 1 &, 011 \\
\hline & $\begin{array}{l}\text { Dersi Anlama ve Öğrenme Konusunda } \\
\text { Birilerinin Yardımına İhtiyaç Duyulması }\end{array}$ & $-1,034$ & ,290 & 12,706 & 1 & ,000 \\
\hline & Dersin Hiç Başarılamayacağının Düşünülmesi &,- 230 & ,310 &, 548 & 1 & ,459 \\
\hline & $\begin{array}{l}\text { Derste Edinilen Bilgilerin Üniversite Yaşantısı } \\
\text { Haricinde de Kullanılacağının Düşünülmesi }\end{array}$ & 283 & ,307 & ,850 & 1 & ,357 \\
\hline
\end{tabular}


Benzer şekilde parametre değeri İstatistiksel olarak anlamlı ve negatif işaretli olan sosyo-demografik karakteristikler için "Not Ortalamasının Aralığı”, Genel Muhasebe-1 dersiyle ilgili mevcut durum ve düşünceler hakkında "Ders İçin Haftalık Ortalama Ayrılan Vakit, Dersi Anlama ve Öğrenme Konusunda Birilerinin Yardımına İhtiyaç Duyulması”, muhasebe dersinde başarıyı etkileyebileceği düşünülmüş faktörler hakkında ders ile ilgili bölüm için "Konuların İşleniş Tarzı, Ders Hakkında Dersi Almış Öğrenciler Tarafından Yapılan Yönlendirmeler”, öğretim elemanıyla ilgili bölüm için "Tecrübeli Olması, Ders Süresince Öğrencilerle Etkileşimini Yitirmemesi, Dersi Slaytlar Yardımı İle İşlemesi” değişkenlerinin değeri bir birim arttığında "Dersten Alınan Harf Notu” düzeyinde sahip olduğu parametre değeri kadar azalışa neden olacaktır. Örneğin, öğretim elemanının derste zamanı etkili ve verimli kullanması faktörü bir birim arttığında dersten alınan harf notu düzeyinde 0,402 birimlik bir artış görülecektir ve dersi anlama ve öğrenme konusunda birilerinin yardımına ihtiyaç duyulması faktörü bir birim arttığında dersten alınan harf notu düzeyinde 1,034 birimlik bir azalış görülecektir.

Ders için Öğretim elemanının yararlanılmasını istediği kaynağın anlaşılır bulunması ve dersi anlama ve öğrenme konusunda birilerinin yardımına ihtiyaç duyulması değişkenlerine göre muhasebe dersinde başarıyı etkileyen faktörler değerlendirildiğinde dersten alınan harf notu düzeyinde yüksek derecede etkili olduğu görülmektedir. Ayrıca dersi hiç başaramayacaklarını düşünenlerin oranı $\% 66,7$ ve dersi anlama ve öğrenme konusunda birilerinin yardımına ihtiyaç duyanların oranı da \%75,6 dır.

\section{SONUÇ}

Bu çalışmada Kahramanmaraş Sütçü İmam Üniversitesi İktisadi ve İdari Bilimler Fakültesi İşletme Bölümü'nde okuyan Genel Muhasebe-1 dersini almış, birinci sınıf ve aynı dersten kalan tüm öğrenciler seçilmiştir. Yapılan anket sonucunda muhasebe dersinde başarıyı etkileyen faktörler üzerinde, sosyo-demografik karakteristiklerin, öğrencilerin alınmış olan Genel Muhasebe-1 dersiyle ilgili mevcut durumlarının ve düşüncelerinin, muhasebe dersi ile ilgili başarıyı etkileyebileceği düşünülen unsurların, öğrenciler ve öğretim elemanları ile ilgili faktörlerin araştırılması ve belirlenmesi amaçlanmıştır. Araştırmanın uygu lama sıralı lojistik regresyon analizi kullanılmıştır. Muhasebe dersi için Probit bağlantı fonksiyonu kullanılarak yapılandırılan sıralı lojistik regresyon modeli gerekli ölçütler (model varsayımının sağlanması, modelde uygunluk istatistikleri ve parametre tahmin tutarlılığı göz önünde bulundurulduğunda en iyi model olarak seçilmiştir. Muhasebe dersi için Tablo 6.5.1.3. de görüldüğü üzere 16 açıklayıcı değişkenin başarı düzeyi üzerinde anlamlı etkilerinin olduğu tespit edilmiştir.

Muhasebe dersi için yapılan analiz sonucunda sosyo-ekonomik karakteristikler, öğrencilerin alınmış olan Genel Muhasebe-1 dersiyle ilgili mevcut durumları ve düşünceleri, 
muhasebe dersi ile ilgili başarıyı etkileyebileceği düşünülen unsurlar, öğrenciler ve öğretim elemanları ile ilgili faktörler değerlendirilmiştir.

Sosyo-demografik karakteristikler için "Öğrencilerin Not Ortalamasının Bulunduğu Aralık" değişkeni muhasebe dersinde başarıyı etkileyen faktör olarak tespit edilmiştir. $\mathrm{Bu}$ durum için genel not ortalaması hakkında gösterilen başarının muhasebe dersine yansıyacağı ve yüksek not ortalamasının muhasebe dersinde de kendisini göstereceği düşünülebilir.

Genel Muhasebe-1 dersiyle ilgili mevcut durum ve düşünceler için muhasebe dersinde başarıyı etkileyebilecek üç anlamlı değişken tespit edilmiştir. "Ders için öğretim Elemanının Yararlanılmasını İstediği Kaynağın Anlaşılır Bulunması" değişkeni değerlendirildiğinde öğrenciler açısından ders kaynağının anlaşılırlığının başarıda etkili olabileceği ve bu durumun dersteki harf notuna olumlu olarak yansıyacağı düşünülebilir. "Ders İçin Haftalık Ortalama Ayrılan Vakit" değişkeni için öğrencilerin muhasebe dersi açısından çalışmaya vakit ayırmaları ve bu vaktin de artırılması durumunda dersteki başarının olumlu düzeyde etkileneceği söylenebilir. Genel Muhasebe-1 dersiyle ilgili mevcut durum ve düşünceler açısından diğer bir anlamlı değişken olan "Dersi Anlama ve Öğrenme Konusunda Birilerinin Yardımına İhtiyaç Duyulması" faktörü değerlendirildiğinde muhasebe dersinde edinilecek başarı için öğrencilerin bir başka kişinin yardımına ihtiyaç duyabileceği ve bu yardımın alınması durumunda dersteki başarının olumlu olarak etkileneceği ve harf notunda da etkisinin görüleceği düşünülebilir.

Muhasebe dersinde başarıyı etkileyebileceği düşünülmüş faktörler hakkında oniki açıklayıcı değişkenin varlığı tespit edilmiştir. Ders ile ilgili bölüm değerlendirildiğinde "Dersin Yeterli Sayıda Örnek Problemler Dahilinde İşlenmesi" değişkeni muhasebe dersinde öğrencilerin başarısı için örnek problemlere ihtiyaç duyulduğu ve dersin örnek problemlerle işlenmesi durumunda harf notu üzerinde olumlu etkiler sağlayacağı söylenebilir. "Konuların İşleniş Tarzı" değişkeni değerlendirildiğinde muhasebe dersinde başarının sağlanabilmesi için dersin işlenişi öğrencilerin ilgisi ve seviyesi göz önünde bulundurularak gerçekleştirildiğinde başarı düzeylerinin artacağı söylenebilir. "Derste Verilen Bilgilerin İş Hayatıyla İlgili Güncel Bilgiler Olması" değişkeni değerlendirildiğinde öğrenciler tarafından derste verilen bilgilerin gelecekte çalışma hayatlarında kullanabilecekleri ve güncel nitelikte olmasının önemsendiği ayrıca derste verilen bilgilerin bu düzeyde olmasının öğrencilerin derse olan ilgi ve alakalarını artırarak başarı seviyelerinde olumlu etkilere sebep olabileceği söylenebilir. Ders hakkında başarı konusunda anlamlı bir başka değişken olan "Ders Saatlerinin Erken Olması" faktörü değerlendirildiğinde ders saatlerinin öğrencilerin başarısında etkili olduğu ve muhasebe derslerinin erken saatlerde yapılmasının başarı düzeyinde olumlu etkilere sebep olabileceği söylenebilir. "Dersin Teori Kısmının Yanında Özgün Uygulamalarla Birlikte Verilmesi" değişkeni değerlendirildiğinde öğrencilerin dersin teori kısmıla edindikleri bilgileri pekiştirebilecekleri özgün nitelikteki uygulamalarla birlikte gerçekleştirildiğinde başarılarında olumlu etkilerin olabileceği söylenebilir. "Ders Hakkında Dersi Almış Öğrenciler Tarafından 
Yapılan Yönlendirmeler” değişkeni değerlendirildiğinde dersi almış ders hakkında bilgili ve tecrübeli öğrencilerin yapacağı doğru yönlendirmelerin dersi alan öğrenciler üzerinde olumlu etkiler oluşturabileceği ve dersteki başarılarını artırabileceği düşünülebilir. Öğretim elemanı ile ilgili bölüm için anlamlı bulunan "Konulara Hakim Olması" ve "Tecrübeli Olması" değişkenleri değerlendirildiğinde öğrencilerin gerekli ve yeterli bilgileri alması açısından bu faktörlerin gerekli olduğu ve öğrencilerin başarılarını olumlu olarak etkileyebileceği söylenebilir. "Sınıf Üzerinde Sağlayacağı Otorite" değişkeni değerlendirildiğinde dersin sağlıklı koşullar altında işlenebilmesi için öğretim elemanının sınıf üzerinde sağlayacağ otoritenin öğrencilerin başarısına etki edeceği ve olumlu derecede etkileyeceği düşünülebilir. Öğretim elemanı açısından başarıyı etkileyen bir başka değişken olarak "Derste Zamanı Etkili ve Verimli Kullanması" faktörü tespit edilmiş ve gerçekleştirilmesi halinde başarıyı olumlu düzeyde etkileyebileceği söylenebilir. "Ders Süresince Öğrencilerle Etkileşimini Yitirmemesi" değişkeni hakkında öğretim elemanının dersi sınıftan bağımsız olmayarak öğrencilerin tepkilerine dikkat ederek işlemesi halinde başarının artırılabileceği söylenebilir. Öğretim elemanı ile ilgili bölüm için anlamlı bulunan son değişkenler olan "Dersi Sınıf Tahtasını Kullanarak İşlemesi" ve "Dersi Slaytlar Yardımı ile İşlemesi" faktörleri değerlendirildiğinde öğretim elemanının dersi sınıf tahtasını kullanarak ve slaytlar yardımı ile işlemesi halinde öğrencilerin başarılarının olumlu düzeyde etkileneceği tespit edilmiştir.

$\mathrm{Bu}$ çalışmada geliştirilen sıralı lojistik regresyon modeliyle, muhasebe dersinde öğrencilerin başarısının artırılması konusunda araştırmacılara yeni bir bakış açısının kazandırılması amaçlanmıştır. Ayrıca muhasebe dersinde başarıyı etkileyen faktörlerin belirlendiği ve tartışıldığı bu çalışmadaki bulguların, muhasebe dersinde öğrencinin daha başarılı olabilmesi için desteklenmesi gereken unsurlar ve motivasyon kaynakları konusunda araştırmac1lara rehberli etmesi düşünülmüştür.

\section{KAYNAKLAR}

Ayboğa, H. (2003), "Globalleşme Sürecinde Ülkemizde Muhasebe Mesleği ve Meslek Mensuplarının Eğitimi”, Marmara Üniversitesi İ̈BF Dergisi, 18 (1), ss. 327-359.

Bilginer, N. (1999), "Lisans Düzeyindeki Muhasebe Eğitiminde Bir Motivasyon Aracı Olarak Sunum Kalitesinin Etkileri”, MuhasebeBilim Dünyası Dergisi, 1(3), Eylül.

Çukacı, Y. C. - Elagöz, İ. (2006), "Muhasebe Derslerinde Kullanılan Öğretim Yöntemleri İle Öğrenme Stillerinin İlişkisinin Ortaya Konulması Ve Dokuz Eylül Üniversitesi İktisadi Ve İdari Bilimler Fakültesi’nde Bir Uygulama”, Dokuz Eylül Üniversitesi İİB Dergisi, 21 (1),ss. 147-164.

Demir, M.- Çam, M.(2006), "Muhasebe Bölümü Öğrencilerinin Muhasebe Öğreniminde Başarılarını Olumsuz Etkileyen Faktörlere İlişkin Bir Araştırma”, Muhasebe ve Finansman Dergisi, (32), ss. 1-11. 
Demirkan, Ş. (2001), "Muhasebe Eğitim Yöntemleri”, XX. Türkiye Muhasebe Eğitimi Sempozyumu, Antalya.

Dursun, A. (2006), Muhasebe Eğitiminde Kalite Arayışı, Seçkin Yayıncılık, Ankara.

Gücenme Gençoğlu, Ü .(2009), Türkiye’de Harf Devriminin Muhasebe Eğitimi Ve Muhasebe Uygulamalarına Etkisi, Akademik Araştırmalar ve Çalışmalar Dergisi (AKAD), 1 (1), ss. 30-37.

Güney, A.(2015), "Muhasebe Eğitiminde Uygulamalı Bilimler Yüksekokullarının Yeri”, Eğitim ve Öğretim Araştırmaları Dergisi, 4 (3), ss. 81-85.

Kızı1, C.- Gencer, K.(2016), "Muhasebe Dersi Alan Öğrencilerin Başarısına Etki Eden Faktörlerin Tespiti: Yalova Üniversitesi'nde Bir Uygulama” İstanbul Medeniyet üniversitesi Siyasal Bilgiler Fakültesi Dergisi, 1 (2), ss. 67-110.

Kutlu, H. A.- Öztürk, S.(2015), "Muhasebe Eğitiminde "Alternatif Ölçme ve Değerlendirme Yöntemleri” Üzerine Görüşler”, Journal of Accounting, Finance and Auditing Studies 1 (4), ss. 1-22.

Özkan, F.- Aksoy, C. (2015), “Ticaret Meslek Lisesi Muhasebe Bölümü Öğrencilerinin İşletmelerde Beceri Eğitimi Uygulaması, Gaziantep İlinde Bir Alan Araştırması”, Bartın Üniversitesi İİBF Dergisi, 6 (12), ss. 283-305.

Özkul, A. S. (2012), “19. Yüzyıl Türk Yükseköğretiminde İşletme Eğitimi”, Süleyman Demirel Üniversitesi Sosyal Bilimler Enstitüsü Dergisi, (16), ss. 223-241.

Şengel, S. (2010), "Sürekli Muhasebe Meslek Eğitiminin Önemi ve Bir Değerlendirme", Muhasebe ve Finansman Dergisi, (47), ss. 81-94.

Tekşen, Ö.- Tekin M.- Gençtürk, M. (2010),"Muhasebe Eğitiminin Değerlendirilmesi: Mehmet Akif Ersoy Üniversitesi’ne Bağlı Meslek Yüksekokulları Öğrencileri Üzerine Bir Araştırma" Muhasebe ve Finansman Dergisi, 46, ss. 100-112.

Tuğay, O.(2014), “Muhasebe Dersi Alan Öğrencilerin Muhasebe Dersine Yönelik Algıları ve Muhasebe Öğretim Elemanlarından Beklentileri Üzerine Mehmet Akif Üniversitesinde Bir Araştırma” Eskişehir Osmangazi Üniversitesi İİBF Dergisi, 9 (3), 48-68.

Yıldırım, S., (2015), “Genel Muhasebe Dersi Alan Öğrencilerin Derse İlişkin Beklentileri ve Başarı Durumlarının Değerlendirilmesi “ Muhasebe ve Denetime Bakış, 14 (44), ss. 1-14.

Yürekli, E.- Gönen, S. (2015), "Muhasebe Meslek Mensuplarının Nitelikli Meslek Mensubu Yetiştirilmesine Yönelik Önlisans Programından Beklentileri”, Kafkas Üniversitesi İktisadi ve İdari Bilimler Fakültesi KAÜ İİBF Dergisi, 6 (10), ss. 301-316. 
Zaif, F.- Ayanoğlu, Y.(2007), "Muhasebe Eğitiminde Kalitenin Arttırılmasında Ders Programlarının Önemi: Türkiye'de Bir İnceleme”, Gazi Üniversitesi İktisadi ve İdari Bilimler Fakültesi Dergisi, 9 (1), ss. 115- 136. 
